Technological University Dublin

ARROW@TU Dublin

\title{
A Bollywood Commercial for Ireland: Filming Ek Tha Tiger in Dublin
}

Giovanna Rampazzo

Technological University Dublin, giovanna.rampazzo@tudublin.ie

Follow this and additional works at: https://arrow.tudublin.ie/aaschmedbk

Part of the Film and Media Studies Commons

\section{Recommended Citation}

Rampazzo, G. (2018) A Bollywood Commercial for Ireland: Filming Ek Tha Tiger in Dublin S. Dibeltulo and C. Barrett ( eds. ), Rethinking Genre in Contemporary Global Cinema, DOI:10.1007 /978-3-319-90134-3_12 165

This Book Chapter is brought to you for free and open access by the School of Media at ARROW@TU Dublin. It has been accepted for inclusion in Books/Book chapters by an authorized administrator of ARROW@TU Dublin.

For more information, please contact arrow.admin@tudublin.ie, aisling.coyne@tudublin.ie, gerard.connolly@tudublin.ie.

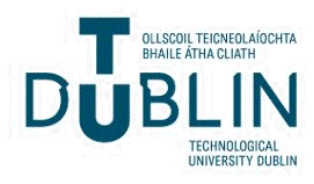


Kääpä, Pietari, and Guan Wenbo. 2011. Santa Claus in China and Wu Xia in Finland: Translocal Reception Networks Between Finland and China Participations 8 (2): 24-51.

Kaukomaa, Tero. 2015. Skype Interview with Pietari Kääpä. April 5.

Kinnuen, Kalle. 2015. Big Game. Kuinka Hollywood tuotiin Suomeen. Helsinki: Johnny Kniga.

Kulturkontakt Nord. 2015. 362000 in KreaNord Grants. Kulturkontakt Nord. Retrieved on April 5, 2017 from http://www.kulturkontaktnord. org/lang-en/nordic-culture-point/news/20-nyheter-om-programmene/1782-kreanord-uddeler-362-000-euro-til-nordiske-projekter.

Larsson, Mariah, and Anders Marklund. 2015. Swedish Film: An Introduction. Lund: Nordic Academic Press.

Nordic Film and Television Fund. 2015. Nordic Genre Boost. Nordisk Film og TV Fond. Retrieved on April 5, 2017 from http://www.nordiskfilmogtvfond. com/index.php/nordic-genre-boost/.

Soila, Tytti (ed.). 2007. The Cinema of Scandinavia. London: Wallflower Press.

Soila, Tytti, Gunnar Iversen, and Astrid Widding. 1998. Nordic National Cinemas. London: BFI.

Suomen elokuvasäätiö. 2007. Elokuvavuosi 2006. Helsinki: SES.

Suomen elokuvasäätiö. 2009. Elokuvavuosi 2008. Helsinki: SES.

\section{A Bollywood Commercial for Ireland: Filming Ek Tha Tiger in Dublin}

\author{
Giovanna Rampazzo
}

The spectacular representation of overseas locations has traditionally been a generic trope of Hindi cinema (AKA Bollywood). Notably, stunning places unfamiliar to Indian audiences are constantly featured in commercial Indian films, mostly for their visual qualities, in order to add a further element of entertainment to the story. In recent times, this representational strategy typical of Bollywood cinema has acquired wider implications in terms of boosting tourism to the films' host countries, resulting in a greater impact of the films' production on local economic and cultural strategies. Significantly, the emphasis of Bollywood films on impressive locations, with images highlighting tourist landmarks, has made them powerful advertising tools for countries interested in drawing visitors to their shores. The purpose of this chapter is therefore to examine how this generic trait of Hindi cinema has been, and continues to be, deliberately employed to draw tourists to host countries. These dynamics will be explored through the specific case study of Kabir Khan's Ek Tha Tiger ("Once There was a Tiger," 2012), an extremely successful Bollywood blockbuster produced by Yash Raj Films, which was partially filmed in Dublin in September 2011.

G. Rampazzo $(\varangle)$

Dublin Institute of Technology, Dublin, Ireland

(C) The Author(s) 2018

S. Dibeltulo and C. Barrett (eds.), Rethinking Genre

in Contemporary Global Cinema,

https://doi.org/10.1007/978-3-319-90134-3_12 
Foregrounding the connections between the making of $E k$ Tha Tiger and the advertisement of Ireland as a tourist destination, this contribution outlines how the showcasing of institutionally constructed images of Dublin resulted in the creation of a "tourist gaze" (Urry 1990) for prospective spectators and potential tourists. By promoting and cultivating the anticipation of a collective viewing experience of a country, cinematic representations can arguably be mobilized in the service of "cultural tourism," through simplified, stereotyped, and spectacular imagery constructions. Drawing on interviews with the film's producers and representatives of Irish institutions, the following exploration foregrounds how the emphasis on sumptuous location that characterizes Bollywood films turned Ek Tha Tiger into an effective promotional vehicle for Dublin. In addition to that, this analysis demonstrates how the resulting depictions provide only a partial view of Irish culture and society, emphasizing appealing and romanticized notions of Irishness.

Impressive locations are characteristic of Hindi cinema, in line with its emphasis on spectacle and entertainment. Other key elements of Bollywood films are song and dance sequences, elaborated costumes, convoluted storylines, lack of sexual display, and a plot involving a mixture of genres including, drama, comedy, action, and romance. This is motivated by the fact that they are intended to entertain the whole family and therefore need to appeal to people of every age and gender. These characteristics have led film commentators to talk about Bollywood cinema as a genre in its own right, often referring to Hindi film as "Masala," a term used to identify a mixture of spices (Desai and Dudrah 2008). However, although Masala films are commonly mistaken to represent all Hindi films as formulaic, they constitute but one generic strand of Bollywood cinema. Hindi film scholar Rajinder Dudrah has identified six Bollywood genres, including Devotional Films, Historical Films, Social Films or Topical, Muslim Social Films, Masala Films, and Romantic Films (2006). Notably, Dudrah cautions that:

[Bollywood films] are not genre films at all in the Western sense of the word. Hindi cinema cannot be forced into Western film-making categories. In one Bollywood film it is possible to include all the Western film genres - musical, romantic, comedy, action, thriller, tragedy, and melodrama. (Dudrah 2006: 48)
However, since the early 2000s, a growing number of popular Indian films have been challenging the conventions of the mainstream, multi-genre, song, and dance Bollywood extravaganzas. They are considerably shorter, often omitting song and dance sequences, and the characteristic mix of comedy, action, romance, and melodrama is replaced by alternative narratives reflecting the changes occurring in modern Indian society. To this end, Neelam Sidhar Wright (2015) argues that post-millennial Bollywood films display a degree of technical experimentation through the use of CGI, special effects, and rapid editing. Moreover, they are characterized by storylines which can fit into genre categories familiar to the West such as science fiction, the gangster film, the horror film. However, she points out that "even within these genre categories, Bollywood maintains a kind of eclecticism, particularly by utilising bricolage, a schizophrenic style, and modes of representation which might depart from generic labelling" (ibid.: 195).

Significantly, Ek Tha Tiger is an example of contemporary Bollywood cinema that reworks familiar themes recurring in traditional Hindi films giving them a new twist, but without rejecting traditional Bollywood formulas. It contains some of the tropes of the standard Hindi film such as action, comedy, and romance, along with song and dance sequences. However, with its tighter plot, elaborated action sequences and unusual locations, it creates a spectacle that appeals to both traditional audiences, interested in the conventional Bollywood fare, and more sophisticated metropolitan viewers. Ek Tha Tiger can actually be described as a romantic thriller, where an Indian secret agent called Tiger (Salman Khan) is sent to Ireland to prevent a Trinity College professor from selling missile technology secrets to Pakistan. Tiger falls in love with the professor's caretaker Zoya (Katrina Kaif), and his secret mission causes the couple to embark on a journey across the world. The film was produced across several countries including India, Ireland, Turkey, Cuba, and Thailand and is the first big-budget Bollywood production ever to be staged in Ireland. For this very reason, the aim of this chapter is to examine the way the city of Dublin was showcased in the film, in line with the intersecting concerns between the production of Ek Tha Tiger and Irish cultural institutions, which benefited from the choice of Dublin as a location. In order to contextualize the case of Ek Tha Tiger within a wider frame of Hindi films used to boost tourism to their host countries, the following section introduces various instances of tourist-oriented representations of overseas locales in recent Bollywood productions. 


\section{Hindi Films and Non-Indian Locations: A Mutually Beneficial Relationship}

Since the 1960s, Bollywood films have incorporated sequences shot in faraway locations. A famous example is Sangam ("Confluence," Kapoor 1964), which was filmed in Italy, Switzerland, and France, establishing a trend for films set in Europe. This tendency has intensified in contemporary films targeting non-resident Indians (NRIs) and middle-class South Asians, which often showcase tourist landmarks and transnational lifestyles. At present, it is customary for Hindi films to be set in the UK, America, or Australia among other countries. This is usually done to enhance Indian audiences' enjoyment of the film through the display of landscapes remote from their everyday experiences. As Grimaud explains in his ethnography of film-making in Mumbai (formerly Bombay), "the viewer takes pleasure in identifying places, but forgets them as it becomes clear why they were chosen: a bit of exoticism" 2003: 227)

The notion of exoticism, understood as an attractive form of difference reminiscent of faraway cultures, can be linked to a heavily contested discourse on the representation of cultural difference. Exoticization and the "tourist gaze" are terms that often arise in discussions regarding Western representations of other cultures. When elements of Indian culture and landscapes are portrayed in non-Indian film productions, they are likely to raise academic debates that negatively highlight their "exoticism," which makes them appealing to Western audiences not familiar with Indian culture. This often applies to films made by South Asian migrant film-makers resident in Western Europe and North America such as Mira Nair, Deepa Mehta, and Gurinder Chadha. Shohini Chaudhuri (2009: 8), in response to the accusation of exoticism levelled at Deepa Mehta's Water (2005), contends that "exoticisation is a common aesthetic strategy in world cinema and needs to be addressed without the customary moral condemnation". She further argues that these practices are not exclusively employed by Western film industries, as "catering to a taste for spectacle and exotica has been a long-standing strategy of Indian popular films" (ibid.: 10). In fact, even if aesthetics of exoticism are usually discussed as appealing to Western audiences, Indian popular films have always employed production strategies that in turn allow Indian audiences to see faraway countries as exotic. According to Chaudhuri,
While the 'tourist gaze' might be characterised as a particular mode of vision signalling aspiration and access to the privileges of modernity and globalization, it is neither exclusively 'white' nor 'Western'... the so-called 'tourist gaze' is returned in Bollywood sequences in Western metropolises. (Chaudhuri 2009: 10)

Significantly, Bollywood sequences set abroad allow Indian audiences to "return the tourist gaze" to recognizable tourist landmarks that represent dream holiday destinations and suggest the appeal of glossy, consumerist lifestyles. London and Switzerland in Dilwale Dulhania Le Jayenge ("The Brave Hearted Will Take Away the Bride," Chopra 1995), New York in Kal Ho Naa Ho ("There May or May Not Be a Tomorrow," Advani 2003), and Sydney in Dil Chahta Hai ("The Heart Desires," Akhtar 2001) are illustrative examples of the way Western locations are portrayed as desirable holiday destinations for Indian audiences. Jigna Desai (2008: 347) argues that these representations are linked to "the rising dominance of Bollywood and the new urban middle class in India engendered by liberalization," suggesting that wealth and consumerism are not just the privilege of white Western people and neither is the mobilization of the "tourist gaze."

Notably, exploring new locations hitherto not seen in Indian film is a deliberate choice of Bollywood film producers. Aman Agrawal, a production executive of Yash Raj Films, pointed out that their films are mainly geared to Indian audiences, so overseas locations are primarily meant to "appeal to audiences in India who love to see new and unusual places" (interview 15 October 2011). Yash Chopra, founder of Yash Raj Films, is renowned for using Swiss locations characterized by idyllic green valleys and snow-capped mountains, as a backdrop for love scenes in his films. Indian films have a history of setting romantic scenes in mountainous areas, and for many years, the region of Kashmir, located in the north west of South Asia, served that purpose. Since the late 1980s, however, Kashmir could no longer be used as a production location due to an ongoing territorial conflict between India and Pakistan. For this reason, film-makers resorted to similar landscapes located overseas to effectively convey the romantic feel in their films. Initially, just a few song sequences were set abroad while the plot was set in India. In the 1990s, however, due to economic liberalization policies, wealthy Indians living both in and outside the Indian subcontinent started to be seen as potential consumers and investors in the Indian national economy. During 
those years, Hindi films began setting entire storylines in overseas locations to target growing communities of middle-class South Asians and NRIs. The most famous example of NRI film is Dilwale Dulhania Jayenge, a romantic comedy about two NRIs living in London who meet and fall in love during a rail trip across Europe. The film was also produced by Yash Chopra and filmed in London, Switzerland, and India, becoming one of the most successful productions of Hindi cinema. Films such as Dilwale Dulhania Le Jayenge boosted tourism to Switzerland to a great extent, and Swiss tourism bodies capitalized on the keen interest of Bollywood fans to visit film locations. Switzerland so far has provided locations for over two hundred Hindi films, attracting hundreds of thousands of tourists every year. Yet Switzerland does not have historical ties to India, nor does it host large Indian communities, suggesting that the vast majority of Indians who visit the country have been attracted by the lush locations featured in Hindi films.

Over the years, it has become apparent that Bollywood productions set abroad played an important role in increasing the influx of Indian tourists to the countries featured in the films. By hosting Hindi film productions, foreign national industries have had the opportunity to use cinema to promote tourism to their countries among wealthy Indian audiences. This has been reinforced by the constant growth of Indian middle classes since the 1990s. In her essay on representations of the West in Bollywood films, Raminder Kaur (2002: 205) argues: "economic liberalisation saw the emergence of a globalised Indian middle class. Their conspicuous consumption patterns revealed a highly materialistic and uninhibited urban middle class, constantly fuelled by growing capitalist ambitions." Following the example of Switzerland, other European countries have tried to secure Bollywood investments as a way to boost tourism from India. Spain, for instance, has benefited from Zoya Akhtar's Zindagi Na Milegi Dobara ("You Don't Live Twice," 2011), a blockbuster which caused visa applications from India to double shortly after its release by featuring several major Spanish landmarks (Munshi 2012). The film effectively boosted Spanish Tourism from India by $65 \%$ in 2011 compared to the previous year. ${ }^{1}$

The protagonists of Zindagi Na Milegi Dobara are seen taking part in the tomato fight, "La Tomatina," in the San Fermin festival bull race, and in flamenco dance routines; these narrative elements allow the film to showcase Spain's natural beauty, its tourist infrastructures, and its culture. The Spanish tourism board thus used Zindagi Na Milegi Dobara to market Spain, and "never before has so holistic and concerted an effort been made on the part of a country's tourism authority and an Indian filmmaker to fully integrate the marketing of a destination into the production, plot and promotion of a major movie" (ibid.).

Since the early 2000 s, Irish government agencies became aware of India's rapid economic growth and of the potential of Hindi films to attract Indian tourists to Ireland. The Irish Film Commissioner, Naoise Barry, explained in an interview that since 2004, the Irish Film Board and Tourism Ireland have been trying to build relationships with leading producers of Bollywood films with limited success until Ek Tha Tiger was secured (interview 13 April 2012). Thus, when Kabir Khan expressed an interest in filming Ek Tha Tiger in Dublin, the Irish government was eager to capitalize on the high profile of the film to promote Ireland as a tourist destination and as a location for more Bollywood films. Since $E k$ Tha Tiger is the first big-budget Bollywood production to make extensive use of Dublin locations to date, it is particularly interesting to study the way it was used to promote investments and tourism to Ireland. Notably, an important part of the activity of the Irish Film Board is actually to promote Ireland as a location for international film and television productions. Since 1997, significant tax incentives have been in place to attract international film industries, and Section 481 of the Irish Taxes Consolidation Act offers up to $28 \%$ tax relief on Irish expenditure for international TV and film ventures co-produced with Ireland. As a result, Ireland has a long history of hosting Hollywood and UK productions, providing locations for large-budget productions such as Saving Private Ryan (Spielberg 1998), Braveheart (Gibson 1995), and Far and Away (Howard 1992)

The Irish Film Commissioner has explained that Tourism Ireland ${ }^{2}$ worked with the Irish Film Board and Dublin City Council to secure Ek Tha Tiger for Ireland. Trinity College, Ireland's oldest and most reputable university, and other government agencies also collaborated in facilitating filming in the city at reduced costs since the film involved complex and expensive scenes, yet did not have the budget of a Hollywood film. Everybody came on board and waived their fees as they saw the potential of what the film could do in terms of publicity, even if they could not imagine that it would be so successful. Before hosting Ek Tha Tiger, the Irish Film Board and Tourism Ireland had limited success in attracting high-profile Indian film productions to Ireland. Having Ek Tha Tiger set in Ireland thus represented a big leap forward in the country's attempts 
to secure Hindi film industry investments, providing a unique opportunity to showcase the beauty of Ireland to a vast number of potential Indian tourists. For this reason, the film became part of an advertising campaign aimed at raising awareness of Ireland as a tourist destination among Indian growing middle classes.

Kabir Khan, the film's director, was instrumental in choosing Dublin as a location for Ek Tha Tiger. He explained that he needed a unique location, a prestigious college with impressive buildings as a backdrop for the storyline, and preferred not to use a British university, since they had appeared many times before in Hindi cinema (interview with RTE News, 6 September 2011). The director had been to Trinity College in 1995 to interview the then President Mary Robinson and was impressed by its architecture, so he decided to use it as a location for the film. As Barry recalls: "it was very good luck on our part in that the first third of the movie takes place in a university ... in this case Kabir knew about Trinity College Dublin, so he called me and asked if we could host a visit for him and his creative team" (interview 13 April 2012). When Yash Raj Films contacted Trinity College enquiring about the possibility to film Ek Tha Tiger on campus, the university had been closed to film crews for almost twenty years. However, Vice-Provost Michael Marsh agreed to the filming, seeing the potential of this project as an advertising tool for the university. Upon the release of the film, delegations from Trinity College went to India to conduct a promotional campaign aimed at attracting prospective students; special screenings of Ek Tha Tiger were hosted in several Indian cities. The filming of $E k$ Tha Tiger proved to be beneficial in raising the profile of the university. To this end, Olivia Waters, a Trinity College representative, stated: "we have seen an increase in activity on the website from India, an increase in applications for our postgraduate scholarships, an increase in interest from schools that we would have had relationships with" (interview 4 October 2012).

\section{EK Tha Tiger as a Promotional Vehicle for Ireland}

The Irish government worked closely with Yash Raj Films who supported Ireland's advertising campaign as part of their production agreement to shoot the film in Ireland. As Avtar Panesar, Vice President of International Operations at Yash Raj Films, noted "we came up with many promos which highlighted Ireland as part of the campaign here, and the Irish Tourism Board actually played these promos out here in
India, because that's the market they wanted to target" (interview 28 February 2013). Yash Raj Films agreed to the film being used to promote Ireland in order to benefit from reduced fees for filming on location. Barry stated that the production benefited from tax incentives, complimentary visas, and reduced location fees, but did not receive any direct funding from Ireland (interview 13 April 2012).

The collaboration between Tourism Ireland and Yash Raj Films in the creation of imagery designed to cultivate curiosity among Indian viewers by portraying Ireland in an alluring way suggests that the construction and development of people's gaze as tourists depends on specific marketing and communication strategies. To this end, Urry and Larsen (2012: 1) argue that "the concept of the gaze highlights that looking is a learned ability and that the pure and innocent eye is a myth." As mentioned at the beginning of this chapter, the tourist gaze is mobilized in Hindi films set in Western locations which are shown as exciting holiday destinations through imagery of tourist landmarks and hedonistic lifestyles. Kaur (2002) has explored the depiction of Western locations in contemporary Bollywood films, suggesting that, since the economic liberalization of the 1990s, Bollywood films have been telling stories of upper-/middle-class Indians living abroad and the Western backgrounds of films shot, for example, in the Swiss Alps, New York, or Sydney provided a sharp contrast to highlight the Indian values promoted by the narrative. According to Kaur (ibid.: 206), "the search for 'authentic' Indian values in the Hindi films, however unintentionally, reveals the long-held images of the West and the eventual making of a celluloid Occident." Western locations are thus used simply as lush and prosperous backgrounds for narratives centred on Indian tradition and family values geared at the growing Indian middle classes of post-liberalization India and at Indians living abroad. In a similar way, the images of Ireland associated with $E k$ Tha Tiger mobilize a superficial view of the city as charming, colourful, and cosmopolitan, encouraging the viewer/tourist to focus on these aspects of the place rather than delving into the complexities of Irish history and society.

Irish Tourism authorities are aware that carefully crafted images of Ireland can potentially lure tourists to visit the country. To this end, the imagery of Ireland promoted by Ek Tha Tiger points to the power of institutions that can decide how representational tropes are articulated in the filmic text through the deliberate inclusion of landmarks and images of prosperity, thus determining what the viewer should see 
and know about a country. Urry and Larsen (2012: 173) examine these dynamics using Foucauldian notions of surveillance and power relations: "following Foucault, we can see this making of seductive images and destinations as an institutional mediation by 'expert gazes' within which spectacle and surveillance intersect and power-knowledge relations are played out." The way Dublin is framed in Ek Tha Tiger reveals how the "expert gaze" of film-makers can be complicit in constructing a tourist gaze for audiences. In fact, overt advertisement for Dublin was discernible across action sequences set in Dublin city centre, showcasing Dublin's most touristic areas. It is interesting to note that most international productions set in Ireland, like, for example, Waking Ned (Jones 1999) and The Closer You Get (Ritchie 2000), do not include urban locations, presenting instead idyllic views of rural Ireland aimed at the American market. This is because they aim at pandering to "a largely mainstream American understanding of Irishness" (Ging 2002: 187). Like most Hollywood action films, Hindi films with a gangster/action theme are mainly set in urban locations: for this reason Ek Tha Tiger shows aspects of Irish urban landscapes and landmarks largely absent from other international films produced in Ireland. Ek Tha Tiger could thus draw the attention of potential visitors to urban tourist activities such as shopping and nightlife.

In one chase sequence, the protagonist follows a Pakistani secret agent across the Temple $\mathrm{Bar}^{3}$ area; a close-up of the sign of the Temple Bar Trading Company ${ }^{\mathrm{TM}}$ helps locate this scene within the city, suggesting the importance of the location, even if this shot has no real relevance in the narrative of the film. This is clearly a way to highlight the shopping opportunities offered by the area and to justify the disruption to businesses caused by the film sets. "Dublin shop owners in general had a positive attitude towards the filming and were happy to come on board as they saw the potential of what the film could do," explained Dermot Cleary, the film's Location Manager (interview 3 September 2012). A rundown area at risk of demolition until the 1980s, Temple Bar is now one of Dublin's main tourist attractions and is widely advertised as "Dublin's cultural and entertainment quarter" and as a site of cultural and historical significance. Temple Bar, however, is what Maeve Connolly (1998: 2) defines as "a large scale example of staged-authenticity." Notably, the colourful shop fronts and impressive façades that characterize the area are actually visible material remnants of the sets of a big-budget Hollywood production, Far and Away (1992). Thus, film sets belonging to an American filmic representation of Ireland are actually advertised as authentic and quin tessentially Irish. Connolly (ibid.: 2) explains that even if the film "was received as highly 'unauthentic', the sets were retained by popular demand and became part of the scenery of Temple Bar." This can be linked to an attempt of the locals to control and direct the tourist gaze in order to prevent tourists from knowing aspects of Irish life and society perceived as irrelevant to outsiders: "apparently authentic back-stages may be artificially created by local people and entrepreneurs to redirect the gaze and hence reduce the degree of intrusion" (Crawshaw and Urry 1997: 178).

\section{The Success of EK THA TIGER}

Ek Tha Tiger was screened in Dublin in August 2012 and was very well received. ${ }^{4}$ Interviews were conducted by the author among members of the audience of various Indian and European backgrounds in order to find out their opinion about the representation of Dublin in the film. Overall, viewers enjoyed the film's song and action sequences, especially the one involving the Luas train, ${ }^{5}$ and liked the way Dublin was portrayed as a young and lively place. They also appreciated the way the beauty of the city was foregrounded. The makers of $E k$ Tha Tiger wanted the locales portrayed in the film to be part of the spectacle expected from a blockbuster. The audience's response suggests they were successful in their intent to show Dublin as a vibrant and exciting city, similar to urban locations usually featured in Western action blockbusters, which rarely focus on the poverty and social issues present in large metropolises. Ek Tha Tiger has been hugely successful: it broke several box-office records in India, and it was praised by most Indian critics as an effective and unconventional piece of entertainment. Taran Adarsh (2012) of Bollywood Hungama rated the film 4.5 stars out of 5 , calling it a "high octane thriller that works big time. This one has style and substance, both, besides dazzling action, stunning international locales and stylish execution." Anupama Chopra (2012) of Hindustan Times gave it 3 stars out of 5 and said that the film was Khan's best since Dabangg ("Fearless," Abhinav Kashyap 2010); it had "more story coherence and emotions than Khan's recent films." In the Irish press, the film was mainly praised for its potential to attract tourists to Ireland (Broadsheet 2012), confirming the notion that the most significant Irish-Indian co-production to date was considered mainly a vehicle for Irish national promotion. 
Significantly, the film moved away from Bollywood generic conventions in the way its script was tight, fast-paced, and free of the convoluted storylines typical of traditional Hindi films. Additionally, the film's female protagonist was not a stereotypical damsel in distress waiting for the hero to save her often seen in Bollywood cinema, but an action heroine in her own right, actively involved in impressive stunts and fight sequences. Like other contemporary Hindi films, Ek Tha Tiger endeavoured to move away from traditional Bollywood conventions and landscapes in order to appeal to middle-class Indian audiences living in big cities and used to watching Hollywood films. As mentioned above, due to the recent growth of Indian middle classes, these metropolitan spectators, together with NRIs, have become the new, sought-after audience for films previously intended mainly for lower-class audiences, who, historically, have preferred traditional storylines but lacked the financial means to visit the locations portrayed in the films. In the months following the release of Ek Tha Tiger in 2012, the Irish Central Statistics Office recorded an increase in tourism from long-haul destinations, and visits to the Tourism Ireland website from Indian IP addresses further increased since the release of the film (Tourism Ireland 2013). Even if no other major Hindi production has to date made use of locations in the Republic of Ireland since Ek Tha Tiger, ${ }^{6}$ the film has nevertheless confirmedly established a foundation for future collaboration between Bollywood production companies and Ireland.

\section{Conclusion}

This discussion has endeavoured to demonstrate how the long-standing emphasis on visual spectacle, a typical generic trait of Bollywood cinema, and its portrayal of unusual and exotic locales has turned films into effective advertising tools for countries hosting Hindi film productions. An examination of the production of Ek Tha Tiger furthermore outlines how the need to appeal to educated metropolitan audiences can prompt Mumbai production companies to explore new locations and agree to their films being used as promotional vehicles for local institutions, in order to achieve spectacular action sequences. Drawing on interviews with members of the film's production team and representatives of Irish institutions, this chapter has outlined how Irish government agencies and Bollywood collaborated in the making of a blockbuster, ostensibly used as an advertising tool to attract Indian tourists, students, and investments to Ireland. This further indicates that Ek Tha Tiger produced a "tourist gaze" for audiences, shaping their perception of Dublin and Irish culture according to institutionally choreographed images of charm and cosmopolitanism. In so doing, the film plays on existing clichés and stereotypes surrounding Irish culture, showcasing postcard-like views of Dublin in line with representations of urban spaces typical of big-budget Western action films. In that these depictions of Irishness were well received by audiences in both Ireland and abroad and proved to be effective in boosting tourism to Ireland, the production of Ek Tha Tiger in Dublin thus confirms the effectiveness of Bollywood generic tropes in constructing spectacular and appealing notions of Irish urban life.

\section{Notes}

1. Over 115,000 Indian tourists visited Spain in 2011 compared to 75,000 in 2010 (Munshi 2012).

2. A government agency in charge of the promotion of Ireland as a tourist destination.

3. Temple Bar is a designated cultural quarter in Dublin situated on the south bank of the river Liffey. It is known for its lively nightlife and its popularity among tourists.

4. Ek Tha Tiger achieved an impressive worldwide gross of 3.25 billion Rupees (39 million Euro) (Boxofficeindia 2013).

5. Luas means "speed" in Irish and is a tram (or light rail system) serving Dublin.

6. The Hindi production Teraa Surroor ("Your Passion," Arranha 2016) was filmed in Dublin in September 2015. Teraa Surroor had a much smaller budget compared to $E k$ Tha Tiger and did not feature major Bollywood stars; therefore it was not actively used to promote tourism to Ireland.

\section{REFERENCES}

Adarsh, Taran. 2012. Ek Tha Tiger. Bollywood Hungama, August 15. Retrieved on August 30, 2012 from http://www.bollywoodhungama.com/ moviemicro/criticreview/id/545809.

"Bollywood Glamour Comes to Dublin." 2011, September 6. Retrieved on September 15, 2011 from https://www.rte.ie/news/ special-reports/2011/0906/305784-bollywood/.

Chaudhuri, Shohini. 2009. Snake Charmers and Child Brides: Deepa Mehta's Water, 'Exotic' Representation, and the Cross-Cultural Spectatorship of South Asian Migrant Cinema. South Asian Popular Culture 7 (1): 7-20. 
"Chennai Express Crosses Ek Tha Tiger Worldwide in Ten Days." 2013, August 19. Retrieved on August 30, 2013 from http://www.boxofficeindia.com boxnewsdetail.php?page $=$ shownews\&articleid $=5979 \&$ nCat $=$.

Chopra, Anupama. 2012. Anupama Chopra's Review: Ek Tha Tiger. Hindustan Times, August 16. Retrieved on August 30, 2012 from http://www.hindustantimes.com/Entertainment/Reviews/Anupama-Chopra-s-review-Ek-Tha Tiger/Article1-914239.aspx\#sthash.IPEZpvVK.dpuf.

Connolly, Maeve. 1998. Postcard from Dublin. SuperUmbau (Interdisciplinary Urban Project Newspaper) 4 (Winter): 1-6.

Crawshaw, Carol, and John Urry. 1997. Tourism and the Photographic Eye. In Touring Cultures: Transformations in Travel and Theory, ed. Chris Rojek and John Urry, 176-195. London: Routledge.

Desai, Jigna. 2008. Bollywood, USA Diasporas Nations and the State of Cinema. In Transnational South Asians: The Making of a Neo Diaspora, ed. Susan Koshy and R. Radhakrishnan, 345-367. New Delhi: Oxford University Press. Desai, Jigna, and Rajinder Dudrah (eds.). 2008. The Bollywood Reader. Maidenhead: Open University Press.

Dudrah, Rajinder. 2006. Bollywood: Sociology Goes to the Movies. London: Sage

Ging, Debbie. 2002. Screening the Green: Cinema Under the Celtic Tiger. In Reinventing Ireland: Culture and the Celtic Tiger, ed. Peadar Kirby, Luke Gibbons, and Michael Cronin, 177-195. London: Pluto Press.

Grimaud, Emmanuel. 2003. Bollywood Film Studio: ou comment les films se font à Bombay. Paris: CNRS Editions.

Kaur, Raminder. 2002. Viewing the West Through Bollywood: A Celluloid Occident in the Making. Contemporary South Asia ll (2): 19-209.

Munshi, Neil. 2012. Spain's Starring Role in Bollywood Movie a Boon to Tourism, February. Retrieved on May 20, 2014 from http://adage. com/article/global-news/spain-s-starring-role-bollywood-movie-aboon-tourism/232511/

"Rupee Tuesday." 2012, August 21. Retrieved on August 30, 2012 from http://www.broadsheet.ie/2012/08/21/rupee-tuesday/.

Tourism Ireland. 2013 "Comment on CSO Figures for December 2012 February 2013." Retrieved on April 10, 2013 from http://www. tourismireland.com/Home!/About-Us/Press-Releases/2013/TourismIreland-Comment-on-CSO-Figures-forDecembe.aspx.

Urry, John. 1990. The Tourist Gaze: Leisure and Travel in Contemporary Societies. London: Sage.

Urry, John, and Jonas Larsen. 2012. The Tourist Gaze 3.0. London: Sage.

Wright, Neelam Sidhar 2015. Bollywood and Postmodernism: Popular Indian Cinema in the 21 st Century. Edinburgh: Edinburgh University Press.
PART V

\section{Genre(s) in a Post-9/11 Context}

